\title{
Academy Meetings
}

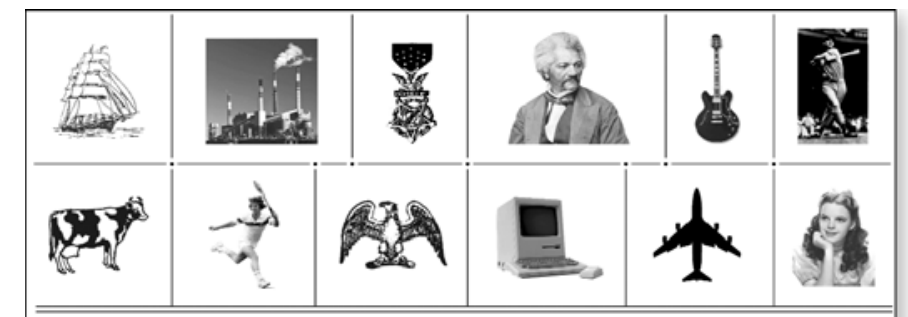

\section{A NEW LITERARY HISTORY OF AMERICA}

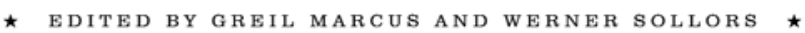

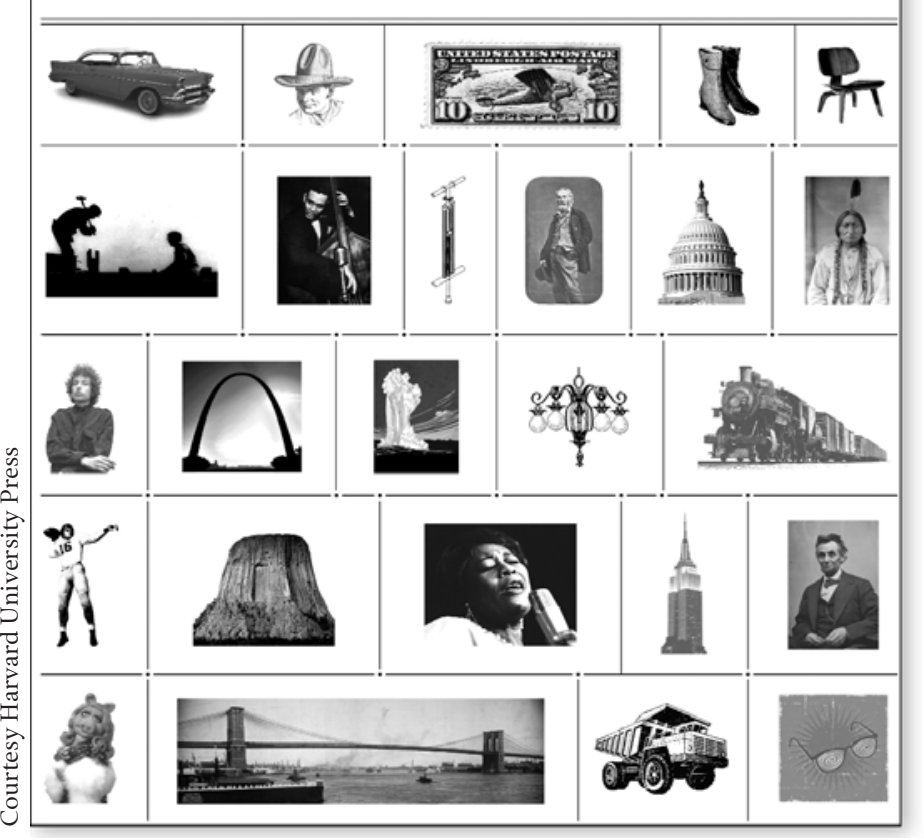

\section{A New Literary History of America}

\author{
Werner Sollors and Greil Marcus \\ Introduction by Emilio Bizzi
}

This presentation was given at the 1945th Stated Meeting held at the House of the Academy on September 24, 2009.

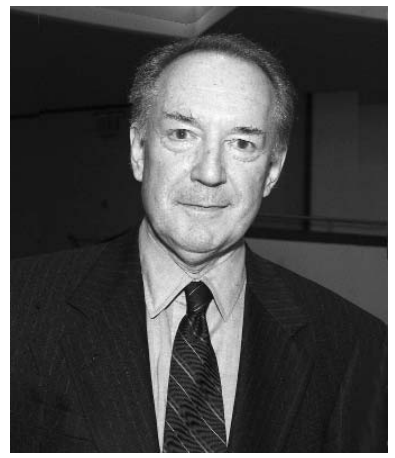

\section{Emilio Bizzi}

Emilio Bizzi is Institute Professor and Investigator at the McGovern Institute for Brain Research at the Massachusetts Institute of Technology. He has been a Fellow of the American Academy of Arts and Sciences since 1980. He served as the Academy's 44th President.
Introduction

T onight, we have the pleasure of hearing from Werner Sollors and Greil Marcus, who will discuss their new book, A New Literary History of America. They have done an incredible job putting together in a single volume a cultural history of the United States in the last four hundred years. They have considered a number of topics, such as fiction, drama, and poetry - but also a number of unconventional genres, such as religious sermons, children's books, political addresses, and other topics, in order to provide a comprehensive view of the cultural currents in the United States. As Werner says in the book, the goal of the project was to produce not a comprehensive encyclopedia but a provocation.
Werner Sollors is the Henry B. and Anne M. Cabot Professor of English Literature and Professor of African and African American Studies at Harvard University. He has been called one of today's foremost Americanists; his writings about ethnicity, literature, race, and history have broadened our understanding of what it means to be American. He was elected a Fellow of the Academy in 2001. His co-editor, Greil Marcus, is a writer, cultural critic, and acclaimed interpreter of the sound and soul of America. His 1975 book, Mystery Train, redefined popular music criticism. 


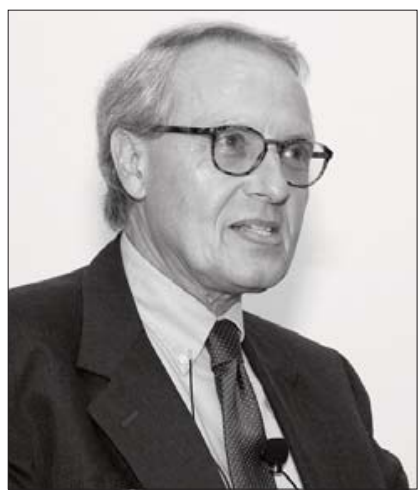

\section{Werner Sollors}

Werner Sollors is the Henry B. and Anne M. Cabot Professor of English Literature and Professor of African and African American Studies at Harvard University. He has been a Fellow of the American Academy of Arts and Sciences since 2001.

$\mathrm{I}_{\mathrm{n}}$ In the course I am teaching now, we turned this week to Mark Twain's Innocents Abroad. I came across the following passage in the book: "The information the ancients didn't have was very voluminous." (This is apropos of passing the Rock of Gibraltar and realizing that they thought it was the end of the world.) Mark Twain continues: "Even the prophets wrote book after book and

\section{The idea emerged to focus on the process of making as something that could hold to- gether a volume on America.}

epistle after epistle, yet never once hinted at the existence of a great continent on our side of the water. Yet they must have known it was there, I should think." How can one address this voluminous lack of information in a literary history at this moment? Javier Solana, then Secretary General of the Council of the European Union, visited Harvard and said that what the European Union needs now is a narrative. "There is no narrative to guide us," he lamented.

I think that also describes the task of literary history today because there is a general fatigue about grand narratives. There is the problem, too, which David Perkins has il- lustrated wonderfully, of limited plot lines in literary history. There always arises a golden age, or there comes a decline. There are avant-garde writers; there are epigonal writers. The story is very quickly exhausted, and it doesn't amount to a very thrilling plot line. And then there are the readily accessible electronic tools that make it much easier today for a student - or for anybody to get to the bare facts, those facts that a nineteenth-century literary historian would have familiarized the reader with by employing a narrative. What do we do in the age of Google with a literary history?

I also think of my own students' experiences with reading literary history. They tend to browse or look for particular information on one author or one moment. Very few students that I know read a literary history from beginning to end.

Thinking of this state of affairs, I was very happy when Lindsay Waters, Executive Editor for the Humanities at Harvard University Press, asked me, almost four years ago to the day, to think of devising an American literary history that would follow the model of the histories that Harvard University Press had published before: A New History of French Literature (1989) and A New History of German Literature (2004). They are organized as assortments of essays held together by a chronological grid. Each essay is introduced with headlines and a particular date, but no attempt is made to create one period narrative or one continuous narrative from beginning to end.

The difficulty we encountered in talking about this project - in hundreds of email messages over the last four years - was the question of, what is the difference when we try to approach American literary history? Obviously, it's a much shorter span than doing a history of German or French literature. Also, with German and French literature, one has a sense of a long-established literary tradition that precedes the emergence of a nation-state. But in the United States, you find so much emphasis on madeup things that are created under our noses: in print pamphlets, for example, we can trace a line from the first visions of what the American colonies could become to such documents as the Declaration of Independence.
We tried to get contributing authors who had not previously published books on topics they were assigned... Our slogan was always that they should surprise not only the readers but also themselves with what they were writing.

Thus the idea emerged to focus on the process of making as something that could hold together a volume on America. When we look around the world today, we see that the whole world either loves or hates America but knows American popular culture really well - much better than after World War II, when the early Americanists had to spread knowledge about writers like Melville and Hawthorne through American studies programs. Now, one can count on the whole world knowing Superman or Rambo or whatever else the popular culture industry has exported. So our idea was to include in the process of making aspects of popular culture, not just of high culture, and we had to select them in a way that would make sense for a volume in which literature is still the central organizing device.

When Greil agreed to become co-editor of the book - which was the happiest moment for me, to think of co-editing a book with Mr. Lipstick Traces - we had to think about the literary strand that could hold together a great variety of topics and genres that includes not only the literary genres Emilio already talked about, but also political texts, the man-made environment, technological inventions, and so forth. We decided on the aspect of literariness: of something that is textual, that can be read, that has a delineation resembling the literary. For example, an entry on Chuck Berry mentions that he wrote an autobiography, so the textual angle is given there. We have a wonderful entry on the Mergenthaler Linotype machine. (Mark Twain, of course, invested in the mechanical typesetter that didn't make it, 
the Paige Compositor, and almost went bankrupt as a result of it.) The Mergenthaler typesetter teaches you interesting things, such as why we say uppercase and lowercase (because that's really how the typesetting worked: with a case that was higher up and a case that was lower), that, again, relate directly to the textual.

With that in mind, we could include topics that would be, in a broad sense, literary from the first map in which the name America appeared to Obama's election, the latter of which was actually an afterthought. When Obama was elected in November 2008, the volume's last entry was an essay on Hurricane Katrina. It seemed important to include the 2008 election, and we thought of asking an artist to comment. It would have been too easy to have a political puff piece of sorts, of inflated hopes, of the rhetoric of the moment. We asked Kara Walker to contribute, and she did a visual piece, a series of her paper cuts with some writing in them. Again, the textual is there, but the writing includes such phrases as WTF and $O M G$ that I think the text messagers among you can easily decode.

\section{The book allows you to}

\section{create your own narrative by reading the essays in a particular sequence.}

The amazement at things that have been created, that have been made, that have been made up is something that permeates the volume, including not only memorable prose but also unforgettable visuals: the moments at which drip paintings, popular tunes, and technologies are created. As we thought of more and more topics, we bounced ideas off each other, saying we really want this and that - even the electric chair was on the board at one point. We began to realize, too, that it would be impossible to have a single volume, even a volume of one thousand pages, that could claim something like complete coverage. We found a very good board of editors who helped us, first, to devise and settle on topics; the board also met with us twice in meetings where we came up with almost four hundred possible topics. We could fit a few more than two hundred essays in the book, so we had to radically reduce the number of essays. We tried to negotiate how we would give enough space to the high canonical authors like Hawthorne, Melville, T. S. Eliot, Faulkner, and O'Neill; to authors who once were canonical such as Longfellow (who gets a very good essay in the book); to middlebrow writers like James Jones, author of From Here to Eternity; to middlebrow institutions, as shown by an entry on the Book-of-the-Month Club; and to writers from minority groups who had no place in some histories of the past, including, for example, Chief Simon Pokagon, one of the first American Indian fiction writers.

The discussion of topics led to surprising double entries where, in order to fit different subjects into one entry, wonderful matches were made. Longfellow and William Carlos Williams appear together as transnational poets. Dreiser and Wharton are together in one essay; T. S. Eliot and D. H. Lawrence in another; Henry Ford and Diego Rivera, brought together by an invitation to lunch that Ford extended to Rivera, in still another. One of my favorites is the pairing of Absalom, Absalom! and Gone with the Wind, both published in 1936 as Southern epics but with quite different trajectories. There's John F. Kennedy's inaugural address together with Joseph Heller's Catch 22, which gives you a sense of the surprising double entries. We tried to get contributing authors who had not previously published books on topics they were assigned; we did not want rehashes of already published writing, but writers who cared about the topics and would try to write surprising things. Our slogan was always that they should surprise not only the readers but also themselves with what they were writing.

Among the contributors are also a great number of contemporary writers who commented on authors of the past: among others, we have Walter Mosley writing on hardboiled fiction, Bharati Mukherjee on The Scarlet Letter, Ishmael Reed on Huckleberry Finn, John Edgar Wideman on Charles Chesnutt, and Andrei Codrescu on the literature of New Orleans.
Greil and I talked about the very protracted process of editing the essays down to the right size. They're all between about 2,200 and 2,500 words, some a little shorter, some a little longer. We also tried to "de-academize" the book, so words like heteronormativity were struck (although I noticed that it appears once in the book, prefaced by "what gender theorists now call”). Greil is also wonderful in getting rid of clichés and filler words.

\section{The book is a response to the predicament that we're in: trying not to devise grand narratives and yet still being able to provide something like a historical overview.}

One of the things I am particularly happy with is the great number of minority writers who are contributors but who don't write in the book about only the minority group with which they are ordinarily associated; the essays on The Great Gatsby, on A Boy's Own Story, on Melville, Wharton, and Dreiser, on The Wizard of $\mathrm{Oz}$, on Tarzan, and on Babbitt offer such examples.

The formal unit that emerges from the predicament of writing cultural history today, or writing literary history, when the narrative is exhausted is a book that allows you to create your own narrative by reading the essays in a particular sequence. The book has a wonderful website (http://newliterary history.com) with twelve essays that you can look at as samplers. It's set up as a deck of cards - "Pick a card, pick any card," as Greil has said - to offer a clue on how to read the book. You can click on a card to have an essay come up, and you can then read it in different ways. You can read the book in chronological sequences, where you read five essays that are all set in 1925 , or you can read it in any genre sequence in which you're interested. It is, in its own form, a response to the predicament that we're in: trying not to devise grand narratives and yet still being able to provide something like a historical overview. 


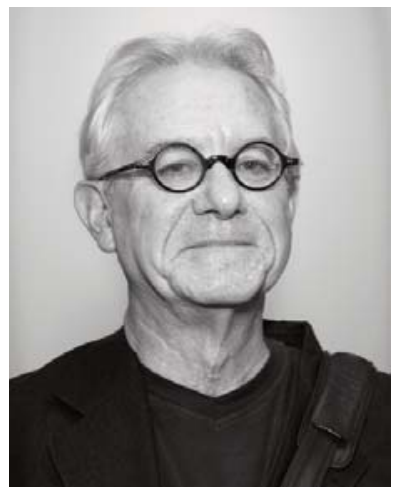

\section{Greil Marcus}

Greil Marcus is an author, rock critic, and columnist. His books include "Mystery Train: Images of America in Rock 'n' Roll Music” (1975), "Lipstick Traces: A Secret History of the 2oth Century" (1989), and "The Shape of Things to Come: Prophecy and the American Voice" (2006).

I 1 would like to emphasize some other aspects of this project, namely its fluidity. We had a wonderful board of ten people who took part in two two-day, early-morninguntil-late-evening marathons without the slightest hint of testiness, of turf defense, of "I know more about this than you do." That sentiment was always absent. I think everybody who took part in this project was stunned by how much they didn't know about what has happened in the last five hundred years in this expansive territory. People were always open.

\section{Every one of these essays is somebody confronting the language of his or her sub- ject and trying to find the language that will open it up.}

Things were made up as we went along. We did have a heroic meeting where we cut everything down to 220 essays, maybe 240. We thought we'd lose some essays by attrition - as if that was going to happen after we'd already argued, discussed, and realized a particular essay was crucial for the book. Then came the point when Gerald Early - essayist, American culture critic, and professor at Washington University in St. Louis - said, "What about Linda Lovelace?" Everybody turned to him, and he wasn't kidding. We said, "What do you mean?" and he said, "This was a cultural turning point. Everything changed after this, and our culture was never the same." The basic argument was this: Here's someone who has written four autobiographies with different "as told tos" and co-writers. Four autobiographies! Two were all about "I was a libertine. I did everything." And two were, "I was a slave. I was forced to do everything." She wrote - she did not invent - but she mined the confessional genre in a way that nobody else had. She both exposed everything she had to expose and hid within that genre, as writers always do. This has been the dominant form of literature in this country over the last thirty or forty years. Who better to represent this genre than Linda Lovelace?

He convinced us. We thought about who could write the piece: Ann Marlowe is a New York writer who wrote a book about heroin and a book about a love affair. She now covers Afghanistan for The Weekly Standard and The Wall Street Journal. She's a very conservative writer politically and a very unconservative writer in every other way. But it turned out to be like my effort to find someone to do the Absalom, Absalom!/Gone with the Wind entry. For that essay, I contacted Lee Smith, who is a great Southern novelist born in Virginia and who now lives in Chapel Hill. She has written, I think, nine novels, my favorite of which is The Devil's Dream. This is a woman in her 6os - a white woman in her 6os who is a deep Southerner. She said, "I've never read Gone with the Wind; I've seen the movie.” I didn't believe it, but she promised she had never read the novel. You can't really say, "I’d like you to take this on; it's only a thousand pages." So I called Bobbie Ann Mason, another Southern writer from Kentucky and about the same age. Again: "I've never read Gone with the Wind; I've seen the movie." I just didn't believe it.

In the same way, when I called Marlowe and said, "Ann, how would you like to write about Linda Lovelace?" she said, "I've never seen Deep Throat.” Here was this cultural illiteracy among people who we thought
In every case, this is a matter of people attempting to talk to their subject matter and make their subject matter talk to them. It is literary in the best, most live, and least pretentious sense.

would be perfect for these contributions. So Ann got a copy of the movie online. It seemed to be a tenth-generation dub, and she said it was very bad, hard to watch even. But Ann dove into those four autobiographies by Linda Lovelace. She excavated those four books. She lived in those four books.

There did come a point during our brainstorming meeting when, as Werner said, we were saying, "Oh, the electric chair!" and "What about the Pez Dispenser?" (I don't think that last one really came up, but it was heading in that direction.) That's when David Thomson, one of the few editorial board members who is not an academic but is a great film critic and film historian, novelist, and social historian, just about pounded the table and said, "This book has got to get a lot more conventional before it gets crazy." We turned around, and we turned back to Emerson, back to Hemingway, back to Jefferson. We began to see that there needed to be anchors before we cut the anchor. We ended up with two entries on Emerson, on “The American Scholar” and "The Divinity School Address," and the easiest thing in the world would have been to find experts on Emerson and have them give us a cool, plain, simple account of how these addresses are touchstones in American culture. But that's exactly what we didn't want and exactly what we didn't get. We got someone who read these addresses as if for the first time and asked questions like, What's going on here? What's happening? Why is this being said now? What does it sound like today? I remember reading those entries and feeling as if I had never before encountered the subjects of those essays. That sense of reve- 
lation happened again and again, and it's why the book is something you can read for pleasure, something that engages the reader through the engagement of the writers themselves.

The most frightening piece for me was Robert O'Meally's on Billie Holiday. The pieces were supposed to be 2,500 words at most, and O'Meally's was clearly over 6,000 words. There is only one way to cut a 6,00oword essay down to 2,500 words: with a meat cleaver. I got it down to about 2,100 words, and it was a very shapely essay then.

Part of what was cut from that essay, though, was a passionate cry about Gayl Jones, an African American novelist who, in the mid1970s, wrote two books, Corregidora and Eva's Man, which got some attention. After that she pretty much disappeared, although she wrote a couple of other novels years later. Her personal life blew up, and she withdrew. People thought she was dead. So O'Meally reshaped his material on Jones, and that became a new entry, on its own terms. Some people have already said, "Gayl Jones? Who knows about Gayl Jones? Who cares about Gayl Jones? What about John Updike? What about Don DeLillo?" Well, what about them? Jones is somebody we put our money on; we put our bet on her. We'll see what happens.

Kara Walker, who contributed the final piece on the 2008 presidential election, said at one point, "I'm too busy. I can't possibly do this." She did say she wanted to make it clear that Harvard would not own the originals of the artwork that she supplied. She said something like, "I'd feel really bad if Harvard owned the originals and then they turned around and sold them for a quarter of a million dollars." I said, "Oh, really. That's interesting.” She didn't mention what she was being paid, which was really kind of that amount reduced by a certain number of zeros. In the end, her attitude was, "I can't possibly say no to this. You're asking me to have the last word in the history of the country? Who could say no to that?" And that's pretty much how people reacted, one after the other. People who we invited to contribute to this book trusted the project more than we did.
We have had a lot of difficulty explaining why this is called A New Literary History of America. What does that mean? We've come up with a lot of really good or not-so-good explanations. But the best came in one of the early reviews of the book. It said, "This is a literary history," stressing the literary. Every one of these essays is somebody confronting the language of his or her subject and trying to find the language that will open it up. In every case, this is a matter of people attempting to talk to their subject matter and make their subject matter talk to them. It is literary in the best, most live, and least pretentious sense - if we've succeeded. If we haven't, we won't have to explain what it's about.

\section{Question}

How did you think about the audience for this book, both your ideal audience and what you really think the audience will be now that it's done?

\section{Werner Sollors}

We talked during the editing process about removing the overly academic language, so we had, first, a general reader in mind, a reader who would not already be an expert on the subject and who would not say, "Oh, but you forgot this and that secondary essay." Rather, we aimed for somebody who would be opening to a subject as if for the

\section{The majority of entries was always literary.}

first time. We also agreed to reduce, perhaps completely remove, references that would imply the book was written only for an American audience. So phrases like "in our tradition" or "in this country," which are hard to translate into Chinese without departing from the original, we tried to avoid. We imagined an intelligent, curious reader anywhere, one who is not a specialist. (I think nobody in the world can be a specialist on all these topics.) That was the ideal that we were going for. I don't know who the real reader is, but that was certainly the ideal we had in mind.

\section{Greil Marcus}

It's a book to be read for pleasure as opposed to enlightenment. It's not a book that's supposed to be good for you in that sense. My ideal reader has always been someone who is walking down the street and trips over a book lying on the sidewalk. After he kicks the book for having tripped him, he picks it up, opens it, and says, “This looks interesting." Every essay here had to have enough information in it so that someone who knew nothing whatsoever about the subject not only could follow what was being said but also could be drawn in and engaged. That was every writer's job. People were not writing for their academic peers or their nonacademic peers. For me, it was the revelation of my own ignorance that was so thrilling. Again and again, I read essays on subjects I know nothing about, and the writer had to be able to suck me in, had to leave me at the end saying, "I want to know more about this." The audience is anybody who thinks this is a really great cover and wonders what's inside.

\section{Question}

I was struck by the impression that you were innovating a kind of emergent process that hadn't existed before - that your process was almost as important as your very creative and innovative product. The hundreds of email messages back and forth, the brainstorming meeting, the figuring out the juxtapositions, and the marathon winnowing meeting: all of that was essential in the creation of this vision of a new kind of literary history. Could you comment more on that and how self-conscious you were of it?

\section{Werner Sollors}

The self-consciousness went to the extent that, in one meeting, somebody proposed that the last entry should be about the publication of the literary history itself, which we fortunately got rid of. But I think the self-consciousness inherent in creating a text such as we were - trying to be textual and literary in approaching American culture more broadly - was certainly there, and it created its own excitement. A number of the members of the editorial board, 
the contributors, and Greil and I felt we were all in the process together. It was, in a sense, the most exciting project I've been a part of in my whole academic life. You had this invigorating feeling of something happening at the moment of deciding this or changing that. Removing, for example, all birth and death dates of authors was a real relief. We said we'd put them in the index, but by the time we got to the index, we forgot about them. You can go to Wikipedia and look them up; we don't need birth and death dates. These were freeing moments in the process that I found very exciting.

\section{Greil Marcus}

Bill Clinton once said something I really liked. I don't know how true it is, but I liked it. He referred to the old democratic principle that most people can do most jobs. (I think he was talking about putting together his cabinet.) That was pretty much the principle we went on: that most intelligent, questioning people can write about damn near anything. We did go to people who

\section{The question that runs}

\section{through this book is this notion that America is made-up, that it is invented and continually remade and reinvented.}

had an interest and who knew something, except sometimes people would say, "I don't know anything about this, but I'll give it my best." Farah Griffin accepted the notion of writing about Edith Wharton's The House of Mirth and Theodore Dreiser's Sister Carrie in one essay because these novels seem to tell the same story in very different ways at pretty much the same time. The story is about a rupture in the idea of what the country was and what it could be. Farah said she wanted to do this, and I said, "Great, Farah, this is terrific." Afterward, she said to me, "You know, I hate Dreiser, and I'm not going to write about him." I thought, "Okay, that was sort of the point, but what the hell." I don't know if she was pulling my leg, but she wrote an essay de- scribing exactly how and where Carrie Meeber and Lily Bart would have met, if they had. And you think, "I didn't realize they met. Oh, wait a minute, they aren't real."

When we reached the end of the book, we realized we had a serious problem. The book was finished. Everything was in; everything was edited. Werner and I were patting each other on the back, and we realized that there were two things we didn't have: an essay on The Sound and the Fury and an essay on MobyDick. I won't go into why that happened, but that's where we were. So we flipped a coin: he did Faulkner; I did Melville. By then, though, we knew what the book was. We knew how people had risen to an occasion we hadn't even fully defined. We knew what we were up against, how high the bar was. People will judge whether we came up to it.

\section{Question}

Did Elvis Presley come into the mix at any point, and if so, is there a good story about how you dealt with him or chose not to deal with him?

\section{Greil Marcus}

That's very tricky. Of course Elvis came up. I felt uncomfortable about it and stayed out of the discussion because I've written a lot about Elvis - two-and-a-half books, actually. The argument was made for Chuck Berry, and as Werner said, this is a literary history. Chuck Berry wrote an autobiography. As a piece of writing, it's extraordinary, just as Bob Dylan's Chronicles is. Both of these books are clearly written, and they weren't written with somebody. You can read and you can see the choices between words that the author has made. This wasn't read into a tape recorder. We thought, this is someone who has shaped his story. He has made an effort to affect how people will understand who he was and what he did. I think there was something in The New York Times about Chuck Berry being chosen over Elvis because he wrote his own songs, and I thought, "Is that why? I don't remember that." That's not a standard I believe in. It was because he wrote an extraordinary book. That's why - and Elvis has gotten a lot of press.

\section{Werner Sollors}

I think that was a full account of the discussion. I can only go back to the point at which we said we are not aspiring to full coverage. Representing something by a suggestive essay that's in the vicinity should be sufficient.

\section{Question}

Can you say more about how you went about keeping those pillars, and whether you consciously crafted the book as a response to more traditional histories of American literature? Did you have the Norton Anthology in front of you to say, this is what we're not doing?

\section{Greil Marcus}

That's a really good question because the Norton Anthology did come up. It might have been placed on the table at some point, and I think the reaction was, "No, we don't want to look at this. We really have to hash this out." In terms of what you' re calling our pillars, there was never a question of Jefferson not being there. There was a question about John Adams and which of his works we were going to write about, but Adams had already broken his way into the room. This meant we had to think in a different mode for the next two hours. Who are the people or what are the works this book absolutely has to have? For the first couple of hours we focused on the "how cool would it be if" standard, and the book was getting away from us. We went back to the question, who does this book absolutely have to have? That was easy, because once you have John Winthrop, Thomas Jefferson, Hemingway, and Frederick Douglass, it becomes easier to drop other people. People begin to look small. That made our work easier.

\section{Werner Sollors}

In the four-hundred-title grid, there was always a preponderance of traditional authors, and one of the things we wanted to do was not take just the modernist canon, but take some of the writers who had been taken away: some of the genteel writing, some of the middlebrow, any of the victims of modernism. The majority of entries, even in the 
larger version, was always literary and had a large substance that was that skeleton. The amazing thing was that we didn't find authors to write about Moby-Dick and The Sound and the Fury. We had the fantasy of including many contemporary writers, so I can tell you the list of contemporary authors I asked to write on The Sound and the Fury who either didn't grace the request with an answer at all or simply said no. Melville and Faulkner were always supposed to be in there and, indeed, are in there: Faulkner with that

\section{The difficulty of setting} fiction that followed European norms on American soil-What could an American Gothic novel be like? Should it have Indian atrocities in it to say something local? - these are the early moments in the book.

half-entry together with Gone with the Wind and Melville with his later writings. But we realized we couldn't do without Moby-Dick and The Sound and the Fury. That's how we ended up writing these entries ourselves. It wasn't that we were becoming conservative at a crucial moment, just that our attempts to get contemporary writers to write about these books had failed, This surprised me, as it seemed to be easier to get contemporary writers to write on a whole variety of other works. I still think it would be a great project to put together a collection of contemporary authors writing a literary history of the past, including personal essays on the writers who meant most or least to them.

\section{Question}

Was the decision to include Norbert Wiener's Cybernetics an easy one? How did you find its place in the pantheon you were creating?

\section{Werner Sollors}

I'm very happy that David Mindell, who wrote the entry, is sitting there in the back. We wanted to have one of the tracks in the literary history be about histories of inventions, technology, and science in the United States. Wiener's book was a perfect example of a text that created a word that created a whole field; it is clearly related to the history of technology. The entry is a fascinating one and dates the book wonderfully. It fits into this post-World War II moment. We were happy with the choice and with the essay that came from it. With the history of technology, we could have very easily had 150 essays about just that, but, again, the inclusion of a text that had enormous consequences made the difference in our selection.

\section{Question}

How are you left feeling or thinking about America?

\section{Greil Marcus}

It was Werner's idea that the book should end with a piece that we would write together on Hurricane Katrina. I didn't really know why he made that suggestion, but it was a challenge - and not just because we had to work together and write something in 2,500 words that wouldn't be redundant upon redundant, given the enormous amount that had already been written about that event. As we thought about it, it raised the question that runs through this book, this notion that America is madeup, that it is invented and continually remade and reinvented. Sometimes those inventions fail. Sometimes they blow up in people's faces. Sometimes they produce the worst consequences with only the best intentions. Sometimes the intentions aren't so great. Hurricane Katrina and the response, both from the federal government and, to some degree, the rest of the country itself, raised the question of whether the country really exists at all as anything more than a marketplace. And that question, we found, came up again and again. If you can make something, if you can invent something as enormous, both as an idea and as the reality of a nation that is also a continent, it can be unmade. If you can make it up, somebody can attack the premises on which you created this thing. Knock all the floorboards out, and that question is alive throughout the book. I'm not going to answer for Werner, but this book left me with a deeper sense than I ever had before of how contingent, delicate, at-risk, in jeopardy this enormous adventure has always been and remains.

\section{Werner Sollors}

I may be the more Pollyannaish and optimistic figure there, but I think the contingency of creativity is certainly something I took from reading so many essays about areas where I had no expertise whatsoever. I'll give you an example. I asked a famous writer to contribute an essay on Henry Roth's Call It Sleep. The writer said, "I cannot do this," and I said, "Why not? You like the book." The writer said, "This is a man who had writer's block; he didn't write anything for sixty years. If I write about his book, I may catch it. I may not be able to write." This was a joke, but the fear that as you face an empty page, as you start to create something from scratch that the creation can stop, is also very real and serious; it can lead to depression, to an implosion of whatever beautiful creativity you thought you had. The sense of contingency in the amazing variety and beauty of things that have been created, be they legal texts or poems or visual objects, and that have defined culture is very present. To see this happening in the various activities is both thrilling and intimidating because you realize the contingency is all based on man-made materials. There's this feeling that it can stop, that the creativity can end. 


\section{Question}

When did American literary history begin? You mentioned John Winthrop, but who are some of the early figures you deal with?

\section{Werner Sollors}

We start with a map that Martin Waldseemüller drew and with Matthias Ringmann, who coined the new continent America after Amerigo Vespucci (adding that since all the other continents had been named after women, he was happy to name the new one after a man). We did not want to open with Columbus because it was highly predictable, although I think the first name in the book, nonetheless, is Columbus, even under the Waldseemüller entry. We have Spanish settlers and then move to the Puritans and early Southern texts fairly quickly. Then it's a more traditional assortment of writers - Charles Brockman Brown, James Fenimore Cooper, Irving, and Hawthorne - so we get a rich array of the early Republic writers. Intermingled are visual texts: there's the Declaration of Independence and Winthrop's Arbella speech. There's also a wonderful essay on the Great Awakening that asks whether there really was such a thing, or whether it was something historians created. The book deals with many familiar topics but also some unusual ones: for example, Charles Willson Peale's exhibition of a mastodon at his museum in Philadelphia and John James Audubon's response to Alexander Wilson's drawing of the bald eagle. The difficulty of setting fiction that followed European norms on American soil - What could an American Gothic novel be like? Should it have Indian atrocities in it to say something local? - these are the early moments in the book.

\section{Greil Marcus}

There's another way of looking at it, too: if this book is successful, the different entries argue with each other over that very question. There's no single essay in which somebody says, this is where American literary history begins; but in some ways, the essays that go up to 1800 are all staking claims. Traditionally, the earliest American literary genre is the Puritan sermon. That's where people began to work out the language needed to describe this place and what it has to become. How to put this into new words was a tremendous struggle. In some

\section{There's no single essay in which somebody says, this is where American literary history begins.}

ways, that defines the whole Puritan experiment. On the other hand, there is a shockingly original entry early on by Adam Goodhart about John Smith as a writer. Suddenly you realize that, no, it's not the sermon.

The first American literary genre is people going back with strange tales of wonder or, in the case of Smith, strange tales of perfidy, envy, and every one of the deadly sins; tales of what the colonists were like and of how the place was hell on earth. Reading this book, I know exactly where American literary history begins; it begins with the Declaration of Independence, the struggle to find the words to define this place. Somebody said, "Okay, we'll just make it up," and that's what happened. When I look at this book a year from now, I'll have a completely different answer.

(C) 2010 by Werner Sollors and Greil Marcus, respectively 